\title{
Gene-Environment Interactions and Epigenetic Basis of Human Diseases
}

\author{
Liang Liu ${ }^{1,2 *}$, Yuanyuan $\mathrm{Li}^{3}$, and Trygve O. Tollefsbol ${ }^{2,3,4,5}$ \\ ${ }^{1}$ Department of Medicine, ${ }^{2}$ Center for Aging, ${ }^{3}$ Department of Biology, ${ }^{4}$ Comprehensive Cancer Center and ${ }^{5}$ Clinical Nutrition \\ Research Center, University of Alabama at Birmingham, AL, USA
}

\begin{abstract}
Most human diseases are related in some way to the loss or gain in gene functions. Regulation of gene expression is a complex process. In addition to genetic mechanisms, epigenetic causes are gaining new perspectives in human diseases related to gene deregulation. Most eukaryotic genes are packed into chromatin structures, which lead to high condensations of the genes that require dynamic chromatin remodeling processes to facilitate their transcription. DNA methylation and histone modifications represent two of the major chromatin remodeling processes. They also serve to integrate environmental signals for the cells to modulate the functional output of their genome. Complex human diseases such as cancer and type 2 diabetes are believed to have a strong environmental component in addition to genetic causes. Aberrancies in chromatin remodeling are associated with both genetically and environmentally-related diseases. We will focus on recent findings of the epigenetic basis of human metabolic disorders to facilitate further exploration of epigenetic mechanisms and better understandings of the molecular cues underlying such complex diseases.
\end{abstract}

\section{Introduction}

The human genome encodes approximately 30,000 genes. It is estimated that over 8,000 human diseases are caused by defects in single genes (Kaplan, 2002). These unifactorial or monogenic diseases, such as cystic fibrosis and hemophilia, are individually rare and affect approximately one percent of the human population. In contrast, the causes of major common diseases, such as cancer and diabetes, are much more complex. They often involve both susceptibility genes and their interactions with the environment. Geneenvironment interactions are thought to be mediated by epigenetic modifications of the genome, and epigenetic changes of the genome often arise in response to changes in the environment (Jaenisch and Bird, 2003). Unlike genetic changes, epigenetic changes are more dynamic and are often reversible, depending on the existence or removal of the inducing factors. Gene-environment interactions can alter gene activities and lead to cascades of cellular events to facilitate the adaptation of an individual cell to its environment. Among various cellular events, gene transcription regulation is a central mechanism, which controls the RNA and subsequent protein productions that are essential in cell functions. The interactions between genes and intracellular protein factors can be viewed as an endogenous geneenvironment interaction (Figure 1). Furthermore, external environmental cues can inflict additional impact on this endogenous interaction by modulating the availability or

*For correspondence. Email liangliu@uab.edu conformation of a specific protein factor. Such effects are subsequently manifested by the onsets of developmental abnormalities and chronic diseases at the organismal level (Figure 1).

In the past two decades, epigenetic control of the genome function has drawn widespread interest with a focus on gene regulation. Epigenetic inheritance describes the heritable changes in gene expression from a cell or multicellular organism to its descendants without that information being encoded in the DNA sequence (Waterland and Jirtle, 2003). During the differentiation of embryonic stem (ES) cells into various tissue stem cells such as neural stem (NS) cells, epigenetic processes are involved to selectively activate a subset of tissue-specific gene expression. Although the DNA content between ES and NS cells is identical, neuronal cells usually maintain the expression of neural-specific genes throughout development. The transmission of such tissue-specific gene expression pattern is also referred to as cellular memory (Cavalli and Paro, 1999), which allows cells of different phenotype but identical genotype to transmit a specific phenotype to their progeny cells even when the phenotype-inducing stimulus is absent. At the organismal level, epigenetic inheritance has been reported recently in different species including plants, yeast, Drosophila, and mammals (Chong and Whitelaw, 2004). This particular form of epigenetic inheritance also raises the possibility of nongenetic inheritance of human diseases from the parents to their offspring, which will be discussed in detail below.

\section{Epigenetic mechanisms in development and diseases} The term epigenetics was first used to describe geneenvironment interactions that lead to manifestations of various phenotypes during development. Epigenetic mechanisms are often involved to switch on or off the genes that produce permanent changes associated with the differentiation of diverse cell types. The importance of epigenetics was not recognized until recent two decades following the observation that abnormal DNA methylation events are associated with cancer (Feinberg and Vogelstein, 1983). For a long time, DNA methylation was believed to be the only epigenetic mechanism (Holliday and Pugh, 1975; Riggs, 1975). Subsequently, chromatin remodeling was identified as another major epigenetic mechanism via posttranslational modifications of histone proteins (Hebbes et al., 1988; Landsberger and Wolffe, 1997). Initial studies of chromatin remodeling were focused on histone acetylation, a reversible biochemical process that confers either open or condensed chromatin conformations to alter gene expressions (Brehm et al., 1998; Magnaghi-Jaulin et al., 1998). Recent advances in the field of epigenetics have also uncovered other histone-based epigenetic codes such 


\section{Epigenetics | Book Buynow!}

Publisher: Caister Academic Press

Editor: Jörg Tost CEA - Institute de Genomique, Centre National de Genotypage, Evry, France

Publication date: March 2008

ISBN: 978-1-904455-23-3

Price: GB $£ 150$ or US $\$ 300$ (hardback).

Pages: xii +404

How to Order . Library recommendation form

\section{Download flyer}

\section{Customers who bought this book also bought: RNA and the Regulation of Gene Expression}

The field of epigenetics has gained great momentum in recent years and is now a rapidly advancing field of biological and medical research. Epigenetic changes play a key role in normal development as well as in disease. The editor of this book has assembled top-quality scientists from diverse fields of epigenetics to produce a major new volume on current epigenetics research.

In this book the molecular mechanisms and biological processes in which epigenetic modifications play a primordial role are described in detail. The first seven chapters describe the different biological mechanisms of the epigenetic machinery including: DNA methylation, histone tails, chromatin structure, nucleosome occupancy, Polycomb group proteins, siRNAs and miRNAs. The following chapters cover the epigenetic systems of plants, the epigenetic profile of embryonic stem cells, cell differentiation, imprinting marks, and random X chromosome inactivation. Further chapters deal with epigenetics in relation to cancers, premature aging, longevity and the developmental origins of disease. The final chapter, describes the fascinating potential transfer of epigenetic information across generations.

This up-to-date volume is a major resource for those working in the field and will stimulate readers of all levels to dive into the fascinating and fast moving field of epigenetics.

Reviews:

"... a significant collection of articles, relating to various aspects of epigenetics. The text is clear and concise and all reports include accurate data and figures. ... will assist researchers in the field and provides an important introductory reference for scientists that want to embark on such research. It is highly recommended for personal and institutional purchase." from Microbiology Today (2008)

"... an excellent collection of advanced review papers on different aspects of the emerging research field of epigenetics ... comprehensive coverage of a complex and newly evolving research domain ... an essential primer for anyone interested in the dynamic evolution of epigenetics research ... One of the greatest strengths of this edited work is the variety of researchers contributing to the dynamics of the work's comprehensive nature ... an excellent resource on general aspects of epigenetics. It will quite effectively cater to the needs of molecular biologists, molecular geneticists, cell and molecular biologists, animal, plant, and crop geneticists, synthetic biologists, biotechnologists, and researchers involved with the fields of stem cell and molecular aspects of cancer research." from Crop Science (2009) 49: 1937-1938. 


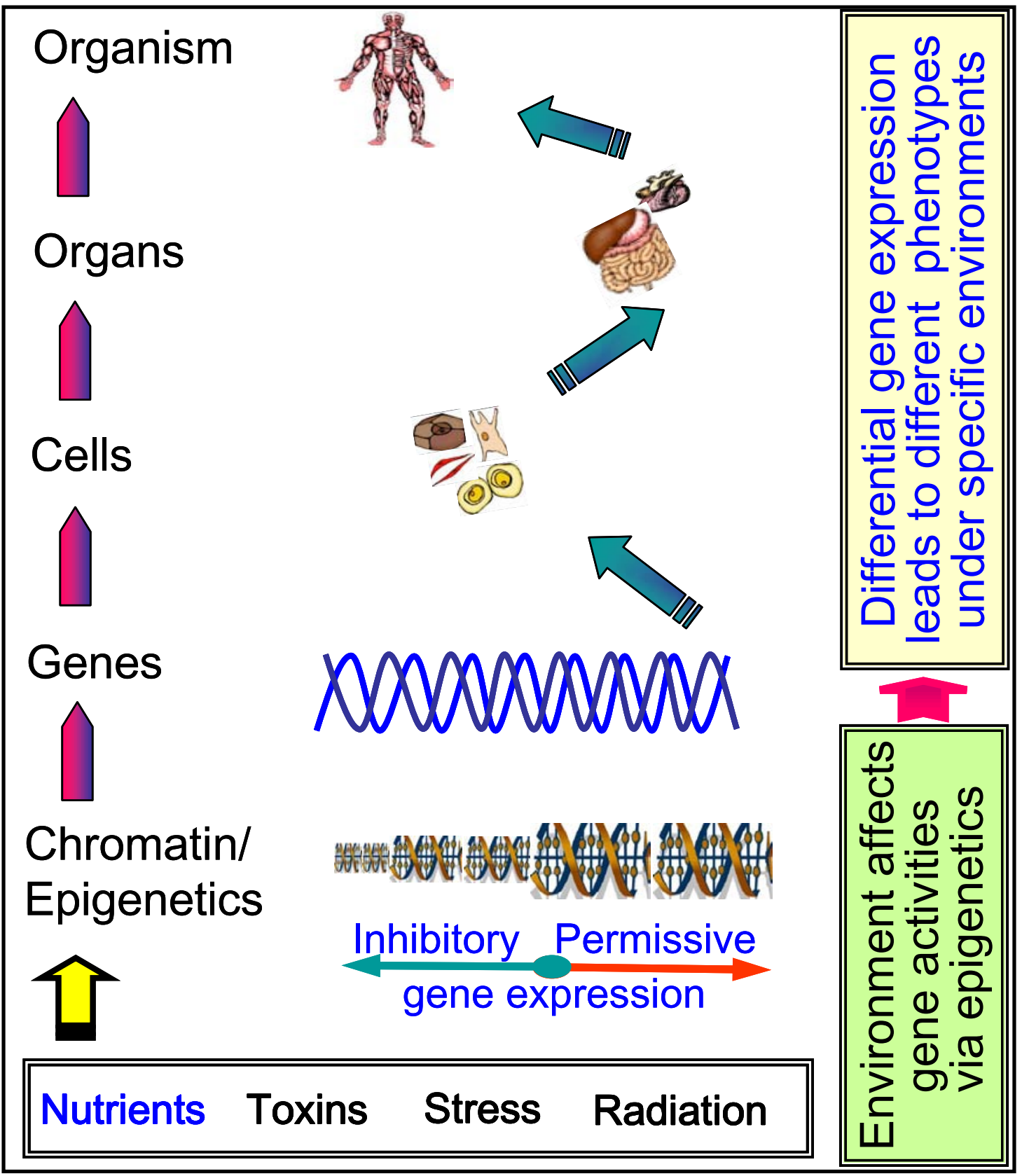

Figure 1. A hierarchical view of gene-environment interactions during development. As depicted, environmental effects are integrated by epigenetic process including chromatin remodeling to either allow or inhibit gene expressions at the molecular level. Such effects will be manifested at the organismal level via ultimate functional output of the genome.

as methylation, sumoylation, ubiquitination, ADP-ribosylation, and biotinylation (Hassan and Zempleni, 2006; Nicholson et al., 2004; Peterson and Laniel, 2004) (Table 1). Although DNA methylation modification of the genome occurs primarily on cytosines located in $\mathrm{CpG}$ dinucleotides, post-translational modifications of histone proteins are much more complex and affect multiple residues (Arg, Lys, Pro, Ser) at over 30 sites within the $\mathrm{N}$-terminal tails of histones (lizuka and Smith, 2003; Jenuwein and Allis, 2001) (Figure 2). Histone methylation alone can appear in the form of mono-, di-, and tri-methylation (Cheung and Lau, 2005). Even more complex, these different forms of methylation can occur on different amino acid residues that are located at different positions (e.g., H3 Lys 4, 9, 27, 36, 79; H3 Arg 2, 17, 16) (Nicholson et al., 2004). Multiple studies have shown that DNA methylation and histone deacetylation can regulate gene expression synergistically through protein mediators such as the methylCpG binding protein MeCP2 (Jones et al., 1998; Nan et al., 1997). Furthermore, epigenetic gene regulation through RNA-associated pathways have been discovered (Fire et al., 1998; Matzke et al., 2001; Matzke and Birchler, 2005). Altogether, these changes are now collectively referred to as epigenetic mechanisms. 


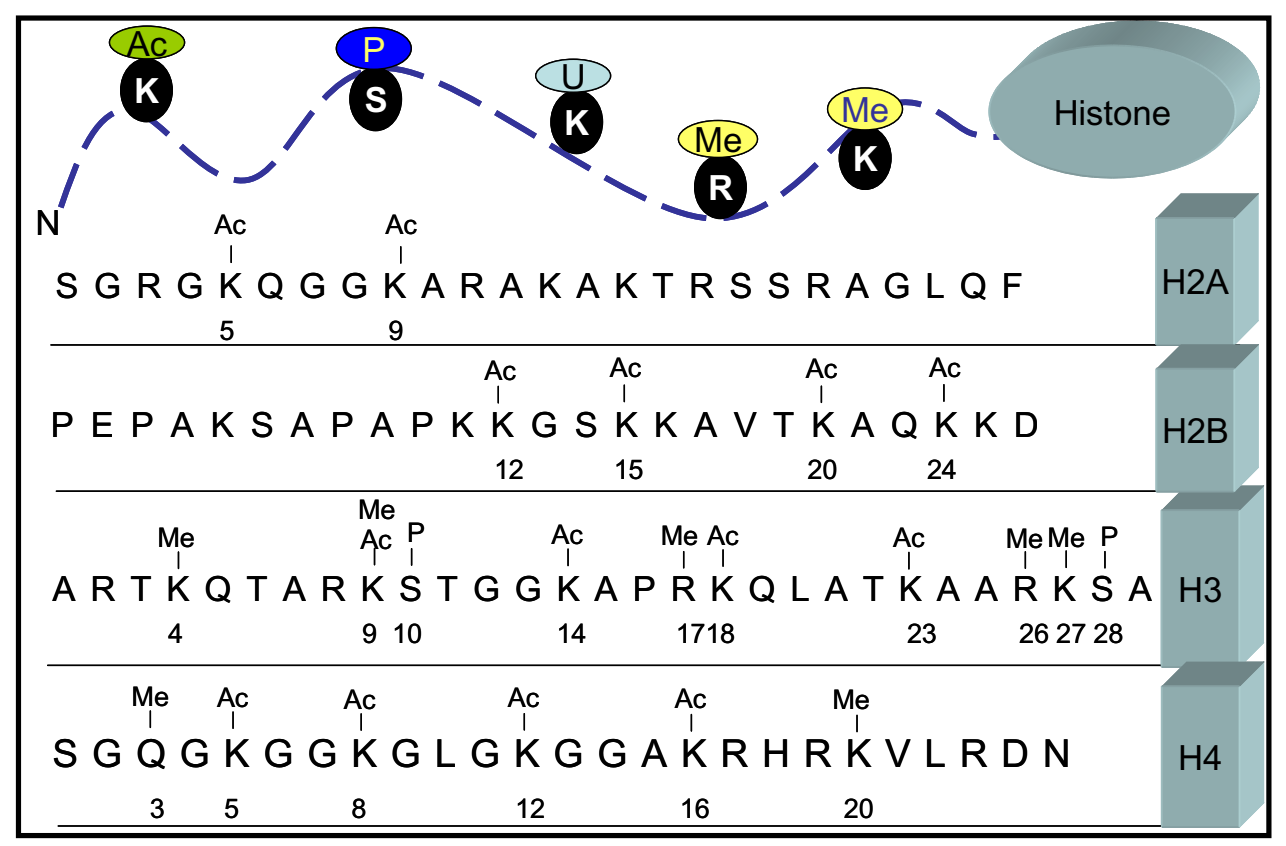

Figure 2. Target sites of the core histone protein tails that are subject to different posttranslational modifications. Ac: acetylation; Me: methylation; P: Phosphorylation; $\mathrm{U}$ : ubiquitination; K: lysine; S: serine; R: Arginine. A complete and frequently updated map of histone modifications is available from http://www.histone.com/ modification_map.htm.

Histone posttranslational modifications

The tight interactions between DNA and histone proteins lead to a high level of structure condensation of genes into chromosomes, which impede gene transcription by default (Han and Grunstein, 1988; Kornberg, 1974; Lorch et al., 1987). The core histones, $\mathrm{H} 2 \mathrm{~A}, \mathrm{H} 2 \mathrm{~B}, \mathrm{H} 3$, and $\mathrm{H} 4$, together

Table 1. A summary of the functional relationship between chromatin modification and gene expression*

\begin{tabular}{|llll|}
\hline $\begin{array}{l}\text { Chromatin } \\
\text { molecules }\end{array}$ & Modifications & Reversibility & $\begin{array}{l}\text { Effect on } \\
\text { gene expression }\end{array}$ \\
\hline DNA & Methylation & Yes & Repression \\
Histones & Acetylation & Yes & Activation \\
& Methylation & Yes & Diverse \\
& Sumoylation & Yes & Repression $^{-}$ \\
& Phosphorylation & Yes & Activation $^{+}$ \\
& Ubiquitination & Yes & Activation $^{+}$ \\
& ADP ribosylation & Yes & Repression $^{+}$ \\
& Biotinylation & Yes & Repression $^{-}$ \\
\hline
\end{tabular}

${ }^{*}$ An inverse correlation between DNA methylation and gene expression, and positive correlation between histone acetylation and gene expression are well established with only a few exceptions. Other modes of histone modifications can either repress or activate gene expression depending on the modified residue and the status of each modification. Methylation of H3-K4 and $\mathrm{H} 3-\mathrm{K} 36$ are generally associated with transcription activation, whereas $\mathrm{H} 3-\mathrm{K} 9$ methylation is associated with transcription repression. The functional consequences for modifications of other residues are not conserved across species (Ebert et al., 2006). Such differences may be related to different mechanisms of recognition and interpretation of histone marks in different species. Other modes of histone modifications have been less well studied, and there also exist opposing results among different studies regarding their effect on gene expression (indicated by "+") (Garcia-Salcedo et al., 2003; Hassan and Zempleni, 2006; Peterson and Laniel, 2004; Zhang, 2003). with 147 base pairs of genomic DNA wrapped around them compose the nucleosomes, the basic units of chromatin. In eukaryotic cells, gene activation is closely associated with covalent modifications of histone N-terminal tails, which are often different between active and silenced chromatins. Acetylation is the most extensively studied modification that can effectively influence gene expression. Acetylation of lysine 14 (K14) or 9 (K9) in histone $\mathrm{H} 3$ by histone acetyltransferase enzymes (HATs) is generally associated with active gene transcription (Nicholson et al., 2004). Furthermore, other modifications such as methylation of histone $\mathrm{H} 3$ at the arginine 17 position (H3meR17), or phosphoacetylation of $\mathrm{H} 3$ at the serine 10/lysine 14 position (H3pS10-acK14), also confer an open chromatin conformation that facilitates transcription (Clayton and Mahadevan, 2003; Valls et al., 2005). The functional relationship between different histone modifications and their effects on gene expression is summarized in Table 1.

Gene activation by histone acetylation is thought to be biophysical in nature. The lysine has a positive charge at its end and can bind tightly to the negatively charged DNA to form a closed chromatin structure to impede the access of transcription factors. Acetylation of lysine residues removes their positive charge and attenuates the charge interaction between histone tails and DNA. This view is initially supported by chromatin immunoprecipitation studies showing that acetylated histones were preferentially associated with actively transcribed beta-globin gene sequences but not with repressed ovalbumin sequences (Hebbes et al., 1988). Furthermore, acetylated chromatin loci are easily accessed and digested by DNA nuclease, whereas the chromatin structure of silenced genes is resistant to DNase digestion (Hebbes et al., 1994; Howe et al., 1998). However, it has been 
argued that acetylation of a small number of residues in histone tails are not sufficient to diminish their ionic interactions with DNA (Peterson and Laniel, 2004). An alternative mechanism proposes that various histone modifications act as docking modules to recruit other chromatin modifying enzymes and basal transcription machinery (Santos-Rosa and Caldas, 2005; Zhang, 2006). For example, a protein segment known as bromodomain can specifically bind to acetylated lysines. The bromodomain is often found in enzymes that help activate transcription including SWI/SNF, an ATP-dependent chromatin remodeling complex (Hassan et al., 2001). Lysine acetylation can recruit the SWI/SNF complex to facilitate transcription activation (Santos-Rosa and Caldas, 2005). Histone H3-K9 methylation is associated with transcriptionally silent chromatin (Mathieu et al., 2005). Proteins with a chromodomain, such as HP1, can specifically bind to methylated-lysine. HP1 is a transcription silencing protein that interacts with histone deacetylase (HDAC) (Nielsen et al., 1999; Zhang et al., 2002). Its binding to methylated H3$\mathrm{K} 9$ results in histone deacetylation that eventually leads to gene silencing (Bannister et al., 2001; Zhang et al., 2002). On the other hand, H3-K4 methylation is recognized by the chromodomain protein $\mathrm{CHD1}$, which can further recruit HATs to activate target gene transcription (Sims et al., 2005). Several recent studies have simultaneously reported that trimethylated $\mathrm{H} 3-\mathrm{K} 4$ serves as the recognition site for the plant homeodomain-containing transcription factors such as the ING (inhibitor of growth) tumor suppressor protein and the BPTF (bromodomain and PHD domain transcription factor) (Li et al., 2006; Pena et al., 2006; Shi et al., 2006). These findings have greatly added to our understandings of how different histone modifications modulate gene transcription.

\section{DNA methylation}

DNA methylation is a fundamental DNA modification that not only modulates gene expression, but also is important for regulating chromosomal stability (Holliday, 2006; Robertson, 2005). DNA methylation is catalyzed by a family of DNA methyltransferases (DNMTs), and is generally associated with gene silencing. The cytosines in $\mathrm{CpG}$ dinucleotides appear to be the favorite substrate for DNMTs. Although a major portion of the genome is unmethylated, $\mathrm{CpG}$ islands associated with gene promoters are subject to dynamic methylation modifications during development (Reik et al., 2001). During DNA replication, the pattern of DNA methylation is copied to the daughter strand by the maintenance DNA methyltransferase DNMT1. There are other DNMTs that can create new DNA methylation patterns in the genome without preexisting methylation information (Lei et al., 1996). These de novo DNMT activities are indicated to play important roles in early development by generating tissue-specific methylation patterns during organogenesis (Okano et al., 1999). Methylation modification of mammalian genome undergoes dramatic changes during early development, which is linked to the rapid differentiation and formation of various tissues and organs (Reik et al., 2001). As differentiation approaches completion, tissues-specific methylation patterns will be established and maintained during later development. Aging in mammals is associated with alterations in the amount and patterns of DNA methylation in somatic cells (Liu et al., 2003). Total genomic deoxymethylcytosine (dMC) generally decrease during aging in various organisms (Mays-Hoopes, 1989). Given that most somatic cells have the potential for a finite number of cell divisions, the loss of overall dMC content in the genome has been proposed to function as a cellular counting mechanism to trigger senescence (Neumeister et al., 2002).

Transcriptional silencing by DNA methylation involves a variety of regulatory proteins including DNMTs, methyl-binding domain proteins (MBDs), histone deacetylases (HDACs) and other chromatin remodeling factors. Accumulating evidence points to the fact that DNA methylation and histone modifications are interrelated in gene regulation in many scenarios (Berger, 2007; Geiman and Robertson, 2002). DNMT1, for example, is shown to associate with HDAC2 and DNMT-associated protein 1 to form a silencing complex, which is recruited to replication foci through interactions with proliferating cell nuclear antigen (Chuang et al., 1997; Rountree et al., 2000). Interestingly, HDAC2 is only associated with DNMT1 during late $S$ phase of the cell cycle, during which period the bulk of transcriptionally inactive heterochromatin is replicated (Rountree et al., 2000). It is possible that HDAC2 is the major player involved in keeping the heterochromatin hypoacetylated. In addition, direct binding of DNMT3a and DNMT1 to HDAC1 was observed (Fuks et al., 2000; Fuks et al., 2001), and histone methylation is also coupled with methylated human Alu elements (Kondo and Issa, 2003). Although many studies have suggested that DNA methylation may act as a primary player in silencing target genes preceding other epigenetic pathways (Hashimshony et al., 2003; Padjen et al., 2005; Schubeler et al., 2000), there are also scenarios where DNA methylation seems to act as a secondary event to stabilize gene silencing status initiated by existing chromatin modifications (Bachman et al., 2003; Mutskov and Felsenfeld, 2004; Tamaru and Selker, 2001). Studies on the kinetics of silencing of transgenes show that loss of histone acetylation and $\mathrm{H} 3-\mathrm{K} 4$ methylation is the first step leading to reversible transcriptional repression, which is followed by H3-K9 methylation and promoter DNA methylation to stabilize the silenced chromatin state (Mutskov and Felsenfeld, 2004). Similarly, it has been shown in Neurospora crassa that trimethylated $\mathrm{H} 3-\mathrm{K} 9$ marks chromatin regions for subsequent DNA methylation (Tamaru and Selker, 2001). These scenarios together indicate a strong cooperation between DNA methylation and histone modifications in regulating gene activities during development. In many cases, disruption of either of those two processes may lead to aberrant gene expression seen in complex human diseases (Rodenhiser and Mann, 2006).

\section{Epigenetic developmental phenomena}

As aforementioned, epigenetic mechanisms participate in mammalian development by facilitating the formation of multiple cell types from a single fertilized egg cell. The DNA content in the fertilized egg contains the core developmental information. As development proceeds, the information is manifested step by step through selective gene expression that is regulated by various factors including epigenetic mechanisms. Classical studies of gene regulation focus on identifying regulatory DNA elements and their interacting transcription factors. Several biological phenomena manifested during mammalian development appear to contradict with the classical Mendelian genetic rules and thus were quite confusing before the knowledge of epigenetics. Examples of such epigenetic developmental phenomena include genomic imprinting, $\mathrm{X}$-inactivation and metastable 
Table 2. A representative list of human diseases associated with epigenetic anomalies.

\begin{tabular}{|c|c|c|}
\hline $\begin{array}{l}\text { Disorder \& estimated } \\
\left.\text { incidence (per } 1 \times 10^{5}\right)\end{array}$ & Candidate genes & Epigenetic anomalies \\
\hline Angelman's syndrome (6) & $\begin{array}{l}\text { Deregulation of the imprinted } \\
\text { UBE3A locus on } 15 q 11-13\end{array}$ & $\begin{array}{l}\text { Disruption of the parental } \\
\text { DNA methylation markers }\end{array}$ \\
\hline ATR-X syndrome (130) & Loss of ATRX function & $\begin{array}{l}\text { Hypomethylation of certain } \\
\text { repeat and satellite sequences }\end{array}$ \\
\hline $\begin{array}{l}\text { Beckwith-Wiedeman } \\
\text { syndrome (10) }\end{array}$ & $\begin{array}{l}\text { Disruption of the imprinted } \\
\text { IGF2/CDKN1C loci on } 11 \mathrm{p} 15.5\end{array}$ & Loss of genomic imprinting \\
\hline Coffin-Lowry syndrome (2) & Mutation in RSK genes & $\begin{array}{l}\text { Disrupted chromatin remodeling } \\
\text { via activation of CBP }\end{array}$ \\
\hline Fragile $X$ syndrome $(50)$ & Loss of FMR1/FMR2 function & $\begin{array}{l}\text { Promoter methylation due } \\
\text { to an expansion of the CGG } \\
\text { repeat }\end{array}$ \\
\hline ICF syndrome $(0.5)$ & DNMT3b mutation & Centromeric DNA hypomethylation \\
\hline Klinefelter syndrome (100) & Extra $X$ chromosome in males & Abnormal X-inactivation/imprinting \\
\hline Prader-Willi syndrome (15) & $\begin{array}{l}\text { Disruption of the imprinted } \\
\text { SNRF/SNRPN locus on } \\
15 q 11-13\end{array}$ & Disruption of genomic imprinting \\
\hline Rett syndrome (8) & MeCP2 mutation & Deregulated promoter activities \\
\hline Rubinstein-Taybi syndrome (1) & $\begin{array}{l}\text { Mutations in the gene encoding } \\
\text { CREB -binding protein }\end{array}$ & Reduced histone $\mathrm{H} 3$ acetylation \\
\hline Williams syndrome (10) & Loss of WSTF function & Condensed chromatin structures \\
\hline
\end{tabular}

epialleles, which will be discussed below. Epigenetic studies in the past two decades have greatly enhanced our understanding of the complex mechanisms underling gene transcription regulation, and have shed insights into the molecular mechanisms underlying such developmental paradoxes that otherwise cannot be addressed solely by genetic studies.

Genomic imprinting is a well-characterized developmental phenomenon that describes a unique form of gene regulation that leads to only one parental allele being expressed depending on its parental origin (Delaval and Feil, 2004; Surani, 1991). The imprinting phenomenon was first observed in early nuclear transplantation studies, where diploid androgenotes derived from two male pronuclei or diploid gynogenotes derived from two female pronuclei failed to develop properly (McGrath and Solter, 1984; Surani et al., 1984). Subsequently, uniparental disomies, in which a single chromosome inherited solely through the maternal or the paternal germline, have been studied in mice to identify regions of the genome that carry imprinted genes (Cattanach, 1986). Insulin-like growth factor 2 (Igf2) and its receptor Igf2r are two of the first reported genes subject to imprinting regulation (Barlow et al., 1991; DeChiara et al., 1991). Currently there are more than 80 genes known to be imprinted in mice and humans, with about one third of those being imprinted in both species (Morison et al., 2005). 600 genes are predicted to be imprinted in the mouse genome (Luedi et al., 2005). Among the identified imprinted genes, a major common feature is that they are associated with at least one regulatory DNA element, often referred to as the imprinting control region (ICR), that is essential in regulating the parental origin-specific expression status via interaction with specific transcription factors (Kim et al., 2007; Yang et al., 2003). Furthermore, these ICRs are often differentially modified epigenetically. Differential DNA methylation of the parental ICRs is one of the most common features associated with imprinted genes (Kim et al., 2003; Liang et al., 2000; Mancini-DiNardo et al., 2003). Such epigenetic imprints undergo erasure and reestablishment during germline development (Kerjean et al., 2000; Reik et al., 2001). Since imprinted genes are functionally haploid, a single mutation or deletion of the functionally active allele would predispose affected individuals to developmental abnormalities. Typical disorders associated with imprinted genes include PraderWilli and Angelman syndromes, Beckwith-Wiedemann syndrome and multiple forms of neoplasia (Weksberg et al., 2003; Zeschnigk et al., 1997) (Table 2). Conversely, aberrant co-expression of both parental alleles, a condition defined as loss of imprinting, has been linked with tumorigenesis (Cui et al., 2003; Jelinic and Shaw, 2007).

$X$ inactivation is a mechanism by which mammals adjust the genetic imbalance that arises from the different numbers of gene-rich $X$-chromosomes between $X X$ females and $X Y$ males. The dosage difference of $X$-linked genes between the two sexes is functionally equalized by silencing one of the two $X$ chromosomes in females. Mammalian $X$ inactivation appears in two forms: imprinted and random $X$ inactivation. Imprinted $X$ activation occurs in early mammals such as marsupials (Graves, 1996). This form of dosage compensation is achieved by inactivating the paternally inherited $X$ chromosome. Imprinted $X$ inactivation also occurs in the extra-embryonic tissues of placental mammals, whereas the cells forming the embryo undergo random $X$ inactivation through which either the paternal or the maternal $X$ chromosome is inactivated (Huynh and Lee, 2001). To achieve random $X$-inactivation, each cell ensures that only one $X$ chromosome remains active and that the other $X$ chromosome is inactivated in a random manner. The differential treatment of two $X$ chromosomes in the same female nucleus results in an active $X(X a)$ and an inactive $X$ (Xi). X-inactivation is a typical developmental phenomenon involving RNA-mediated epigenetic silencing. The underlying mechanism is linked with a noncoding RNA called Xist, which is unique to placental mammals (Duret et al., 2006). The Xist RNA, which is expressed exclusively from and coats the $\mathrm{Xi}$, can spread over and encompass the Xi. Tsix, an antisense 
gene of $X i s t$, also participates in maintaining inactivation. Tsix overlaps with the Xist gene and is transcribed in the antisense orientation (Boumil et al., 2006; Lee et al., 1999). On Xi, Xist RNA coats the chromosome to repress Tsix expression; on $\mathrm{Xa}$, Tsix RNA blocks Xist transcription and the Xist-mediated $X$-inactivation is therefore inhibited. Multiple studies have established that differential DNA methylation and histone modification states exist between $\mathrm{Xi}$ and $\mathrm{Xa}$ (Goto et al., 2002; Hansen, 2003; Heard et al., 2001; O'Neill et al., 1999). $\mathrm{Xi}$ is hypermethylated in $\mathrm{CpG}$ islands and in gene promoter regions, and displays histone $\mathrm{H} 4$ hypoacetylation (AllamanPillet et al., 1998; Jeppesen and Turner, 1993; Keohane et al., 1998). However, Xist is hypermethylated on Xa and unmethylated on Xi (Allaman-Pillet et al., 1998), which allows its exclusive expression from the $\mathrm{Xi}$. Tsix is also regulated by differential methylation of its enhancers between the $\mathrm{Xi}$ and $X a$ in mice (Boumil et al., 2006). Taken together, differential chromatin modifications and RNA-mediated gene silencing appear to constitute the core molecular basis for mammalian $\mathrm{X}$-inactivation.

Metastable epiallele (ME) is another example of epigenetic developmental phenomenon. It refers to the fact that some mammalian alleles display an unusual characteristic of variable expressivity in the absence of genetic heterogeneity (Rakyan et al., 2002). Two extensively studied examples of $\mathrm{ME}$ are the mouse agouti viable yellow $\left(A^{\mathrm{vy}}\right)$ and axin fused $\left(\right.$ Axin $\left.^{\mathrm{Fu}}\right)$ alleles (Rakyan et al., 2002). ME formation is often associated with the insertions of retroelements such as the intracisternal A particle (IAP) retrotransposons (Dolinoy et al., 2006; Vasicek et al., 1997). The $A^{v y}$ allele is formed by an IAP insertion into the mouse agouti gene transcription start site (Duhl et al., 1994), and the Axin Fu allele is formed after an IAP insertion into intron 6 of the mouse Axin gene (Vasicek et al., 1997). The long terminal repeats (LTRs) of IAPs function as the promoter to initiate its transcription following its insertion into the host sequences. It is noteworthy, however, that no single-copy endogenous gene in mammals has been shown to behave in the same way as the IAP insertion alleles. Because IAP transcription is tightly controlled by its LTR methylation status (Mietz and Kuff, 1990; Walsh et al., 1998), expression of the resulting ME alleles also becomes sensitive to DNA methylation. DNA methylation in the $A^{v y}$ IAP correlates inversely with ectopic Agouti expression. Since DNA methylation states are easily perturbed by environmental factors such as nutrients, phenotypic mosaicism will arise from methylation differences among individuals (variable expressivity) due to different environment exposure. $A^{v y}$ allele in mice has become a useful experimental marker for studying epigenetic inheritance (Waterland and Jirtle, 2003; Wolff et al., 1998). Since the degree of methylation varies among individual isogenic $A^{v y} / a$ mice, there is a wide variation in coat color ranging from yellow phenotype with maximum ectopic agouti overexpression (unmethylated), to an array of varied agouti/yellow phenotypes due to partial agouti overexpression (partial methylation), and to a pseudoagouti phenotype with minimal agouti expression (methylated) (Morgan et al., 1999). Yellow (Av/a) mice are often larger, obese, hyperinsulinemic, and more susceptible to tumorigenesis as compared with their non-yellow siblings. Pseudoagouti $A^{v y} / a$ mice are lean, healthy, and long lived as compared with their yellow siblings. $A^{v y}$ expression and subsequent fur color in the offspring have been shown to be modulated by maternal diet (Wolff et al., 1998), providing an mechanistic insight into how nutrient supplies during pregnancy affect the health and longevity of the offspring. Using this unique ME experimental system, a recent study demonstrated that such inheritable maternal effects are mediated by epigenetic changes in the germline induced by nutritional interference, and has led to an intriguing research area known as transgenerational epigenetic inheritance (Cooney, 2006; Cropley et al., 2006).

\section{Transgenerational epigenetic inheritance}

Transgenerational epigenetic inheritance refers to the biological process that an epigenetic state established in the parent either stochastically or in response to the environment can be inherited by the offspring (Chong and Whitelaw, 2004). It was first described in plants (Brink et al., 1968), and was later observed in yeast, Drosophila, and mouse both at transgenes and endogenous alleles (Cavalli and Paro, 1999; Grewal and Klar, 1996; Rakyan et al., 2002), although it is not yet clear whether it occurs in humans (Rakyan et al., 2002). Epigenetic inheritance is thought to result from the incomplete clearing of epigenetic marks during either primordial germ cell development or early embryonic development (Chong and Whitelaw, 2004). Many nutrients, especially those involved in biological methylation pathways, have been shown to influence DNA methylation stability either locally or genome-wide (Liu et al., 2003). To elucidate whether nutritional changes in grandparents may affect offspring development via altered DNA methylation, Cropley and colleagues took advantage of the $A^{v y} \mathrm{ME}$ mouse model by crossing the a/a female mice with the $A^{v y} / a$ males (P1). During mid-gestation between E8.5 and E15.5, they supplemented the pregnant $\mathrm{P} 1$ females with methyl donors such as betaine, folic acid and methionine, all of which are known to enhance genomic methylation. The resulting F1 pseudoagouti females were mated to a/a males and fed with normal diet without further supplementation of methyl donors. It turned out that the ratio of agouti fur color was significantly higher in F2 offspring from supplemented grandmothers than those from grandmothers fed with control diet (Cropley et al., 2006). This increased agouti ratio is likely due to the inheritance of methylated $A^{v y}$ alleles from the grandmother supplemented with methyl donor. The degree of change in offspring fur color is similar between the F1 and F2 generations, indicating that methylation changes at the $A^{v y}$ locus is stably maintained throughout germline development in both F1 and F2 generations (Cropley et al., 2006). This study demonstrated for the first time that specific nutrients can induce epigenetic change at a specific gene locus and confirmed that epigenetic mechanism is a major player in transgenerational inheritance of early environmental effects.

Evidence supporting epigenetic inheritance also comes from studies of the biological effects of endocrine disruptors, which are environmental toxins that interfere with the endocrine system and disrupt the physiological function of hormones by acting as estrogens or antiestrogens or antiandrogens. Examples of environmental endocrine disruptors include pesticides (such as methoxychlor), fungicides (vinclozolin), insecticides (trichlorfon), and various xenoestrogens (Anway and Skinner, 2006). A recent study suggests that environmental endocrine disruptors are detrimental to reproduction, and may promote abnormalities such as a decrease in sperm count, and an increase in testicular cancer (Anway et al., 2005). Transient exposure of a gestating female rat during the period of gonadal sex 
determination to vinclozolin (an antiandrogenic compound) or methoxychlor (an estrogenic compound) induced an adult phenotype in the F1 generation of decreased spermatogenic capacity (cell number and viability) and increased the incidence of male infertility (Anway et al., 2005). These effects were transferred through the male germ line to nearly all males of subsequent generations from F1 to F4. Interestingly, the effects on reproduction appear to correlate with altered DNA methylation patterns in the germ line, as comparative analysis of DNA methylation revealed that vinclozolin exposure altered methylation patterns in the testis (Anway et al., 2005). Although it is not determined which genes are responsible for the resulting phenotypes, a subset of imprinted genes are proposed to be the candidate carriers of such transgenerational effects because germline reprogramming of their methylation markers are more prone to environmental changes (Reik et al., 2001). In addition to methyl donors and endocrine disruptors, glucose has also been implicated to trigger transgenerational inheritance phenotypes (Aerts and Van Assche, 2006; Gauguier et al., 1990). Altogether, these observations highlight the biological importance of epigenetic actions inflicted by environmental agents, and provide a mechanistic view on how epigenomeenvironment interactions can lead to developmental abnormalities independent of genetic changes. The ability of an environmental factor to reprogram the germ line and to promote a transgenerational disease state has significant implications for disease etiology. These recent progresses lay important foundations for future efforts to elucidate the etiology of complex human diseases. Apparently, identifying specific candidate genes involved in these processes will be a major focus for future studies.

\section{Epigenetic mechanisms in metabolic disorders}

Metabolic syndrome (MetS) is a combination of medical disorders that increase the risk for common chronic diseases such as obesity, cardiovascular disease, and diabetes. It is also known as syndrome $\mathrm{X}$, insulin resistance syndrome, obesity syndrome, or Reaven's syndrome. While the MetS term is getting widely accepted in the research literature, there is still an ongoing debate over its clinical utility and whether MetS qualifies to stand alone as a disease condition for clinical diagnoses (Kahn et al., 2005). It is estimated that over $20 \%$ of adults in the US have MetS and the incidence is rising at an elevated rate (Zarich, 2006). The recent explosion of MetS poses a severe health threat to the general population (Grundy, 2004). The fetal basis of adult disease (FeBAD) theory proposes that metabolic disorders have a developmental origin and are related to early nutrition during gestation and lactation (Hales and Barker, 2001). This theory has gained extensive support from recent epidemiological studies showing that fetal undernutrition, lower birth weights, and obesity in humans are associated with an increased risk of diabetes, congestive heart failure, and stroke (Lawlor et al., 2005). Traditional genetic tools are sufficient for uncovering the underlying causes for monogenic diseases; however, the genetic basis underlying the pathogenesis of complex MetS diseases largely remains unknown so far. Major metabolic diseases such as type 2 diabetes (T2D) and obesity are often polygenic and multifactorial in nature. Development of T2D is a multistep process with strong genetic and environmental influences (Smith and Ravussin, 2005; Speakman, 2004). T2D is associated with older age and obesity. Although genetic components underlying obesity development are supported by overwhelming evidence (Rankinen et al., 2006), non-genetic mechanisms are gaining new perspectives (Koza et al., 2006; Speakman, 2004), including a growing interest in epigenetic mechanisms such as DNA methylation and genomic imprinting (Gallou-Kabani and Junien, 2005; Smith et al., 2006). Despite some sporadic studies exploring the epigenetic control of several individual genes related to diabetes and obesity, more systematic efforts are needed for this emerging area of research that holds the promise for unraveling the complex molecular events leading to human MetS (Gallou-Kabani and Junien, 2005).

Many imprinted genes are implicated to be involved in regulating growth and metabolism (Charalambous et al., 2003; Smith et al., 2006; Varrault et al., 2006). Interestingly, disrupted expressions of imprinted genes are found in developmental syndromes displaying features typical of diabetes and obesity, two of the hallmarks of MetS (Delrue and Michaud, 2004). For example, Beckwith-Wiedemann syndrome (BWS) is a developmental disorder that is caused by a variety of genetic or epigenetic alterations within two imprinted domains (Maher and Reik, 2000; Sparago et al., 2007). BWS patients display fetal and postnatal overgrowth, which is associated with defective expression of imprinted genes such as IGF2, H19 and CDNK1C (Smith et al., 2006). Imprinted genes control the supply of nutrients in the placenta and regulate tissue growth in the fetus (Constancia et al., 2004). Imprinted genes also play a key role in postnatal development. The imprinted GNAS domain encodes multiple gene products including the G-protein $\square\left(\mathrm{G}_{\mathrm{s}} \square\right)$ subunit, Nesp55 (maternally expressed) and the neuroendocrinespecific $\mathrm{G}_{\mathrm{s}} \square$, isoform $\mathrm{XL} \square \mathrm{s}$ (paternally expressed). Maternal or paternal transmission of the mouse Gnas knockout produces opposite effects on energy metabolism: loss of the paternal Gnas function causes a decrease in adiposity, hypermetabolic function, and hypoglycemia, whereas loss of the maternal Gnas function leads to greater adiposity (Plagge et al., 2004). The preadipocyte factor-1 (Pref-1) is a paternally expressed gene encoding a transmembrane protein. Disruption of Pref-1 in mice results in reduced body weight at birth (Moon, 2002). Paradoxically, transgene-based Pref-1 overexpression also causes lower birth weight and has been suggested to function as a paternal inhibitor of adipogenesis (Lee et al., 2003). Other imprinted genes that are involved in regulating growth and metabolism include Peg1, Peg3, Plag4 and Hyma1 (Curley et al., 2004). In a high fat-induced obesity mouse model, Peg1 expression showed a 23-fold increase in obese mice as compared to normal controls (Koza et al., 2006). Interestingly, both Peg1 and Peg3 are strongly expressed in the hypothalamus and septum (Constancia et al., 2004; Keverne, 2001). Given the key role of hypothalamic neurons in regulating energy homeostasis (hunger/satiety and food intake), these genes are believed to regulate growth and metabolism through neural programming. Furthermore, Peg1 and Peg3 also appear to regulate adipose tissue growth. Oligonucleotide microarray analyses reveal that Peg1 and Peg3 are upregulated in the adipose tissues from diet-induced obesity mice (Moraes et al., 2003). Consistent with these findings, overexpression of Peg1 can increase the size of adipocytes (Takahashi et al., 2005). Because the expression of imprinted genes is strictly controlled by epigenetic mechanisms, these studies will lead to further characterizations of the underlying epigenetic changes in 
energy metabolism as related to the etiology of MetS.

Adipogenesis refers to the formation of adipocytes from preadipocytes (Rosen and Spiegelman, 2000). It is one of the most intensely studied models of cellular differentiation due to the availability of in vitro models that faithfully recapitulate most of the critical aspects of adipocyte formation in vivo. More recently, studies of adipogenesis have proceeded with the hope that manipulation of this process in humans may facilitate the battle against obesity and diabetes. Several studies have investigated epigenetic regulation of key adipogenic gene activities during in vitro adipogenesis, including the adipose most abundant transcript 1 (apM1), the glucose transporter Glut4, and glycerol phosphate dehydrogenase Gpd1 (Musri et al., 2006). H3 hyperacetylation and $\mathrm{H} 3-\mathrm{K} 4$ trimethylation, for example, are positively correlated with apM1 transcription during early adipogenesis; whereas treatment with methylthioadenosine (an inhibitor of H3-K4 methylation) decreases apM1 expression as well as adipogenesis (Musri et al., 2006). The obese gene leptin is highly expressed in mature adipocytes but not in preadipocytes (MacDougald et al., 1995), which is consistent with the observation that its promoter is highly methylated in human preadipocytes and becomes demethylated in adipocytes (Melzner et al., 2002). Promoter demethylation and consequent expression of the leptin and glut4 genes are also observed during mouse preadipocyte differentiation (Yokomori et al., 1999; Yokomori et al., 2002). The secreted frizzled related protein (SFRP) 5 is an inhibitor of Wnt signaling in adipogenesis. In a high-fat induced obese mouse model, SFRP5 expression was upregulated significantly to promote adipogenesis, and its upregulation was implicated to be due to epigenetic modifications (Koza et al., 2006). These findings together argue for an epigenetic regulation of adipogenesis and obesity development. Dietary components such as folic acid and choline can interact with biological DNA methylation process (Ghoshal et al., 2006; McCabe and Caudill, 2005; Niculescu et al., 2006). Nutrition imbalance can thus lead to DNA methylation aberrancies that affect the activities of key adipogenic genes, which facilitates the development of obesity and other MetS.

\section{Conclusions}

Epigenetic modifications are key regulators of developmental processes including differentiation, growth, and aging. Variations in epigenetic modifications can contribute to genetic diversity, whereas abnormal epigenetic changes often lead to developmental abnormalities and diseases. Advances in understanding epigenetic mechanisms have shed important insights into the complex mechanisms underlying tumorigenesis and also have opened up new therapeutic options and targets for treating cancer patients. Although the role of epigenetic alterations in cancer is widelyacknowledged, the relevance of epigenetics to common metabolic diseases remains less conspicuous to date. Epigenetic studies of obesity, T2D and other related metabolic disorders are still in its early stage. We have summarized some converging data that highlight the significance of epigenetic mechanisms in modulating gene activities in response to environmental influences during development. Due to the polygenic and multifactorial nature of most complex human diseases, complementing classical genetic research with emerging epigenetic tools will be the ultimate method of choice to explore the molecular causes underling the development of complex human diseases. Understanding how small molecules (nutrients and chemicals) interact with the epigenome will allow us to design a new generation of epigenetic drugs for curing complex diseases such as cancer and MetS.

\section{Acknowledgements}

We would like to thank Susan G. Komen for the Cure for grant support as well as the American Institute for Cancer Research, the National Cancer Institute and the UAB Center for Aging.

\section{References}

Aerts, L., and Van Assche, F. A. (2006). Animal evidence for the transgenerational development of diabetes mellitus. Int J Biochem Cell Biol 38, 894-903.

Allaman-Pillet, N., Djemai, A., Bonny, C., and Schorderet, D. F. (1998). Methylation status of CpG sites and methyl-CpG binding proteins are involved in the promoter regulation of the mouse Xist gene. Gene Expr 7, 61-73.

Anway, M. D., Cupp, A. S., Uzumcu, M., and Skinner, M. K. (2005). Epigenetic transgenerational actions of endocrine disruptors and male fertility. Science 308, 1466-1469.

Anway, M. D., and Skinner, M. K. (2006). Epigenetic transgenerational actions of endocrine disruptors. Endocrinology 147, S43-49.

Bachman, K. E., Park, B. H., Rhee, I., Rajagopalan, H., Herman, J. G., Baylin, S. B., Kinzler, K. W., and Vogelstein, B. (2003). Histone modifications and silencing prior to DNA methylation of a tumor suppressor gene. Cancer Cell 3, 89-95.

Bannister, A. J., Zegerman, P., Partridge, J. F., Miska, E. A., Thomas, J. O., Allshire, R. C., and Kouzarides, T. (2001). Selective recognition of methylated lysine 9 on histone $\mathrm{H} 3$ by the HP1 chromo domain. Nature 410, 120-124.

Barlow, D. P., Stoger, R., Herrmann, B. G., Saito, K., and Schweifer, N. (1991). The mouse insulin-like growth factor type-2 receptor is imprinted and closely linked to the Tme locus. Nature 349, 84-87.

Berger, S. L. (2007). The complex language of chromatin regulation during transcription. Nature 447, 407-412.

Boumil, R. M., Ogawa, Y., Sun, B. K., Huynh, K. D., and Lee, J. T. (2006). Differential methylation of Xite and CTCF sites in Tsix mirrors the pattern of $X$-inactivation choice in mice. Mol Cell Biol 26, 2109-2117.

Brehm, A., Miska, E. A., McCance, D. J., Reid, J. L., Bannister, A. J., and Kouzarides, T. (1998). Retinoblastoma protein recruits histone deacetylase to repress transcription. Nature 391, 597-601.

Brink, R. A., Styles, E. D., and Axtell, J. D. (1968). Paramutation: directed genetic change. Paramutation occurs in somatic cells and heritably alters the functional state of a locus. Science 159, 161-170.

Cattanach, B. M. (1986). Parental origin effects in mice. J Embryol Exp Morphol 97 Suppl, 137-150.

Cavalli, G., and Paro, R. (1999). Epigenetic inheritance of active chromatin after removal of the main transactivator. Science 286, 955-958.

Charalambous, M., Smith, F. M., Bennett, W. R., Crew, T. E., Mackenzie, F., and Ward, A. (2003). Disruption of the imprinted Grb10 gene leads to disproportionate overgrowth by an Igf2-independent mechanism. Proc Natl Acad Sci U S A 100, 8292-8297. 
Cheung, P., and Lau, P. (2005). Epigenetic regulation by histone methylation and histone variants. Mol Endocrinol 19, 563-573.

Chong, S., and Whitelaw, E. (2004). Epigenetic germline inheritance. Curr Opin Genet Dev 14, 692-696.

Chuang, L. S., Ian, H. I., Koh, T. W., Ng, H. H., Xu, G., and Li, B. F. (1997). Human DNA-(cytosine-5) methyltransferasePCNA complex as a target for p21WAF1. Science 277, 1996-2000.

Clayton, A. L., and Mahadevan, L. C. (2003). MAP kinasemediated phosphoacetylation of histone $\mathrm{H} 3$ and inducible gene regulation. FEBS Lett 546, 51-58.

Constancia, M., Kelsey, G., and Reik, W. (2004). Resourceful imprinting. Nature 432, 53-57.

Cooney, C. A. (2006). Germ cells carry the epigenetic benefits of grandmother's diet. Proc Natl Acad Sci U S A 103, 17071-17072.

Cropley, J. E., Suter, C. M., Beckman, K. B., and Martin, D. I. (2006). Germ-line epigenetic modification of the murine A vy allele by nutritional supplementation. Proc Natl Acad Sci U S A 103, 17308-17312.

Cui, H., Cruz-Correa, M., Giardiello, F. M., Hutcheon, D. F., Kafonek, D. R., Brandenburg, S., Wu, Y., He, X., Powe, N. R., and Feinberg, A. P. (2003). Loss of IGF2 imprinting: a potential marker of colorectal cancer risk. Science 299, 1753-1755.

Curley, J. P., Barton, S., Surani, A., and Keverne, E. B. (2004). Coadaptation in mother and infant regulated by a paternally expressed imprinted gene. Proc Biol Sci 271, 1303-1309.

DeChiara, T. M., Robertson, E. J., and Efstratiadis, A. (1991). Parental imprinting of the mouse insulin-like growth factor II gene. Cell 64, 849-859.

Delaval, K., and Feil, R. (2004). Epigenetic regulation of mammalian genomic imprinting. Curr Opin Genet Dev 14, 188-195.

Delrue, M. A., and Michaud, J. L. (2004). Fat chance: genetic syndromes with obesity. Clin Genet 66, 83-93.

Dolinoy, D. C., Weidman, J. R., and Jirtle, R. L. (2006). Epigenetic gene regulation: Linking early developmental environment to adult disease. Reprod Toxicol.

Duhl, D. M., Vrieling, H., Miller, K. A., Wolff, G. L., and Barsh, G. S. (1994). Neomorphic agouti mutations in obese yellow mice. Nat Genet 8, 59-65.

Duret, L., Chureau, C., Samain, S., Weissenbach, J., and Avner, P. (2006). The Xist RNA gene evolved in eutherians by pseudogenization of a protein-coding gene. Science 312, 1653-1655.

Ebert, A., Lein, S., Schotta, G., and Reuter, G. (2006). Histone modification and the control of heterochromatic gene silencing in Drosophila. Chromosome Res 14, 377-392.

Feinberg, A. P., and Vogelstein, B. (1983). Hypomethylation distinguishes genes of some human cancers from their normal counterparts. Nature 301, 89-92.

Fire, A., Xu, S., Montgomery, M. K., Kostas, S. A., Driver, S. E., and Mello, C. C. (1998). Potent and specific genetic interference by double-stranded RNA in Caenorhabditis elegans. Nature 391, 806-811.

Fuks, F., Burgers, W. A., Brehm, A., Hughes-Davies, L., and Kouzarides, T. (2000). DNA methyltransferase Dnmt1 associates with histone deacetylase activity. Nat Genet 24, 88-91.

Fuks, F., Burgers, W. A., Godin, N., Kasai, M., and Kouzarides,
T. (2001). Dnmt3a binds deacetylases and is recruited by a sequence-specific repressor to silence transcription. Embo J 20, 2536-2544.

Gallou-Kabani, C., and Junien, C. (2005). Nutritional epigenomics of metabolic syndrome: new perspective against the epidemic. Diabetes 54, 1899-1906.

Garcia-Salcedo, J. A., Gijon, P., Nolan, D. P., Tebabi, P., and Pays, E. (2003). A chromosomal SIR2 homologue with both histone NAD-dependent ADP-ribosyltransferase and deacetylase activities is involved in DNA repair in Trypanosoma brucei. Embo J 22, 5851-5862.

Gauguier, D., Bihoreau, M. T., Ktorza, A., Berthault, M. F., and Picon, L. (1990). Inheritance of diabetes mellitus as consequence of gestational hyperglycemia in rats. Diabetes 39, 734-739.

Geiman, T. M., and Robertson, K. D. (2002). Chromatin remodeling, histone modifications, and DNA methylationhow does it all fit together? J Cell Biochem 87, 117-125.

Ghoshal, K., Li, X., Datta, J., Bai, S., Pogribny, I., Pogribny, M., Huang, Y., Young, D., and Jacob, S. T. (2006). A folate- and methyl-deficient diet alters the expression of DNA methyltransferases and methyl $\mathrm{CpG}$ binding proteins involved in epigenetic gene silencing in livers of $\mathrm{F} 344$ rats. J Nutr 136, 1522-1527.

Goto, Y., Gomez, M., Brockdorff, N., and Feil, R. (2002). Differential patterns of histone methylation and acetylation distinguish active and repressed alleles at X-linked genes. Cytogenet Genome Res 99, 66-74.

Graves, J. A. (1996). Mammals that break the rules: genetics of marsupials and monotremes. Annu Rev Genet 30, 233-260.

Grewal, S. I., and Klar, A. J. (1996). Chromosomal inheritance of epigenetic states in fission yeast during mitosis and meiosis. Cell 86, 95-101.

Grundy, S. M. (2004). Obesity, metabolic syndrome, and cardiovascular disease. J Clin Endocrinol Metab 89, 2595-2600.

Hales, C. N., and Barker, D. J. (2001). The thrifty phenotype hypothesis. Br Med Bull 60, 5-20.

Han, M., and Grunstein, M. (1988). Nucleosome loss activates yeast downstream promoters in vivo. Cell 55 , 1137-1145.

Hansen, R. S. (2003). X inactivation-specific methylation of LINE-1 elements by DNMT3B: implications for the Lyon repeat hypothesis. Hum Mol Genet 12, 2559-2567.

Hashimshony, T., Zhang, J., Keshet, I., Bustin, M., and Cedar, H. (2003). The role of DNA methylation in setting up chromatin structure during development. Nat Genet 34, 187-192.

Hassan, A. H., Neely, K. E., and Workman, J. L. (2001). Histone acetyltransferase complexes stabilize swi/snf binding to promoter nucleosomes. Cell 104, 817-827.

Hassan, Y. I., and Zempleni, J. (2006). Epigenetic regulation of chromatin structure and gene function by biotin. J Nutr 136, 1763-1765.

Heard, E., Rougeulle, C., Arnaud, D., Avner, P., Allis, C. D., and Spector, D. L. (2001). Methylation of histone H3 at Lys- 9 is an early mark on the $X$ chromosome during $X$ inactivation. Cell 107, 727-738.

Hebbes, T. R., Clayton, A. L., Thorne, A. W., and CraneRobinson, C. (1994). Core histone hyperacetylation co-maps with generalized DNase I sensitivity in the chicken beta-globin chromosomal domain. Embo J 13, 
1823-1830.

Hebbes, T. R., Thorne, A. W., and Crane-Robinson, C. (1988). A direct link between core histone acetylation and transcriptionally active chromatin. Embo J 7, 1395-1402.

Holliday, R. (2006). Epigenetics: a historical overview. Epigenetics 1, 76-80.

Holliday, R., and Pugh, J. E. (1975). DNA modification mechanisms and gene activity during development. Science 187, 226-232.

Howe, L., Ranalli, T. A., Allis, C. D., and Ausio, J. (1998). Transcriptionally active Xenopus laevis somatic $5 \mathrm{~S}$ ribosomal RNA genes are packaged with hyperacetylated histone $\mathrm{H} 4$, whereas transcriptionally silent oocyte genes are not. J Biol Chem 273, 20693-20696.

Huynh, K. D., and Lee, J. T. (2001). Imprinted X inactivation in eutherians: a model of gametic execution and zygotic relaxation. Curr Opin Cell Biol 13, 690-697.

lizuka, M., and Smith, M. M. (2003). Functional consequences of histone modifications. Curr Opin Genet Dev 13, 154160.

Jaenisch, R., and Bird, A. (2003). Epigenetic regulation of gene expression: how the genome integrates intrinsic and environmental signals. Nat Genet 33 Suppl, 245-254.

Jelinic, P., and Shaw, P. (2007). Loss of imprinting and cancer. J Pathol 211, 261-268.

Jenuwein, T., and Allis, C. D. (2001). Translating the histone code. Science 293, 1074-1080.

Jeppesen, P., and Turner, B. M. (1993). The inactive X chromosome in female mammals is distinguished by a lack of histone $\mathrm{H} 4$ acetylation, a cytogenetic marker for gene expression. Cell 74, 281-289.

Jones, P. L., Veenstra, G. J., Wade, P. A., Vermaak, D., Kass, S. U., Landsberger, N., Strouboulis, J., and Wolffe, A. P. (1998). Methylated DNA and MeCP2 recruit histone deacetylase to repress transcription. Nat Genet 19, 187191.

Kahn, R., Buse, J., Ferrannini, E., and Stern, M. (2005). The metabolic syndrome: time for a critical appraisal. Joint statement from the American Diabetes Association and the European Association for the Study of Diabetes. Diabetologia 48, 1684-1699.

Kaplan, J. (2002). Genomics and medicine: hopes and challenges. Gene Ther 9, 658-661.

Keohane, A. M., Lavender, J. S., O'Neill, L. P., and Turner, B. M. (1998). Histone acetylation and $X$ inactivation. Dev Genet 22, 65-73.

Kerjean, A., Dupont, J. M., Vasseur, C., Le Tessier, D., Cuisset, L., Paldi, A., Jouannet, P., and Jeanpierre, M. (2000). Establishment of the paternal methylation imprint of the human $\mathrm{H} 19$ and MEST/PEG1 genes during spermatogenesis. Hum Mol Genet 9, 2183-2187.

Keverne, E. B. (2001). Genomic imprinting and the maternal brain. Prog Brain Res 133, 279-285.

Kim, J., Kollhoff, A., Bergmann, A., and Stubbs, L. (2003). Methylation-sensitive binding of transcription factor $Y Y 1$ to an insulator sequence within the paternally expressed imprinted gene, Peg3. Hum Mol Genet 12, 233-245.

Kim, J. D., Hinz, A. K., Choo, J. H., Stubbs, L., and Kim, J. (2007). YY1 as a controlling factor for the Peg3 and Gnas imprinted domains. Genomics 89, 262-269.

Kondo, Y., and Issa, J. P. (2003). Enrichment for histone $\mathrm{H} 3$ lysine 9 methylation at Alu repeats in human cells. J Biol Chem 278, 27658-27662.
Kornberg, R. D. (1974). Chromatin structure: a repeating unit of histones and DNA. Science 184, 868-871.

Koza, R. A., Nikonova, L., Hogan, J., Rim, J. S., Mendoza, T., Faulk, C., Skaf, J., and Kozak, L. P. (2006). Changes in gene expression foreshadow diet-induced obesity in genetically identical mice. PLoS Genet 2, e81.

Landsberger, N., and Wolffe, A. P. (1997). Remodeling of regulatory nucleoprotein complexes on the Xenopus hsp70 promoter during meiotic maturation of the Xenopus oocyte. Embo J 16, 4361-4373.

Lawlor, D. A., Ebrahim, S., and Davey Smith, G. (2005). Association of birth weight with adult lung function: findings from the British Women's Heart and Health Study and a meta-analysis. Thorax 60, 851-858.

Lee, J. T., Davidow, L. S., and Warshawsky, D. (1999). Tsix, a gene antisense to Xist at the X-inactivation centre. Nat Genet 21, 400-404.

Lee, K., Villena, J. A., Moon, Y. S., Kim, K. H., Lee, S., Kang, C., and Sul, H. S. (2003). Inhibition of adipogenesis and development of glucose intolerance by soluble preadipocyte factor-1 (Pref-1). J Clin Invest 111, 453-461.

Lei, H., Oh, S. P., Okano, M., Juttermann, R., Goss, K. A., Jaenisch, R., and Li, E. (1996). De novo DNA cytosine methyltransferase activities in mouse embryonic stem cells. Development 122, 3195-3205.

Li, H., Ilin, S., Wang, W., Duncan, E. M., Wysocka, J., Allis, C. D., and Patel, D. J. (2006). Molecular basis for site-specific read-out of histone $\mathrm{H} 3 \mathrm{~K} 4 \mathrm{me} 3$ by the BPTF PHD finger of NURF. Nature 442, 91-95.

Liang, L., Kanduri, C., Pilartz, M., Svensson, K., Song, J. H., Wentzel, P., Eriksson, U., and Ohlsson, R. (2000). Dynamic readjustment of parental methylation patterns of the 5 '-flank of the mouse $\mathrm{H} 19$ gene during in vitro organogenesis. Int J Dev Biol 44, 785-790.

Liu, L., Wylie, R. C., Andrews, L. G., and Tollefsbol, T. O. (2003). Aging, cancer and nutrition: the DNA methylation connection. Mech Ageing Dev 124, 989-998.

Lorch, Y., LaPointe, J. W., and Kornberg, R. D. (1987). Nucleosomes inhibit the initiation of transcription but allow chain elongation with the displacement of histones. Cell 49, 203-210.

Luedi, P. P., Hartemink, A. J., and Jirtle, R. L. (2005). Genomewide prediction of imprinted murine genes. Genome Res 15, 875-884.

MacDougald, O. A., Hwang, C. S., Fan, H., and Lane, M. D. (1995). Regulated expression of the obese gene product (leptin) in white adipose tissue and 3T3-L1 adipocytes. Proc Natl Acad Sci U S A 92, 9034-9037.

Magnaghi-Jaulin, L., Groisman, R., Naguibneva, I., Robin, P., Lorain, S., Le Villain, J. P., Troalen, F., Trouche, D., and Harel-Bellan, A. (1998). Retinoblastoma protein represses transcription by recruiting a histone deacetylase. Nature 391, 601-605.

Maher, E. R., and Reik, W. (2000). Beckwith-Wiedemann syndrome: imprinting in clusters revisited. J Clin Invest 105, 247-252.

Mancini-DiNardo, D., Steele, S. J., Ingram, R. S., and Tilghman, S. M. (2003). A differentially methylated region within the gene Kcnq1 functions as an imprinted promoter and silencer. Hum Mol Genet 12, 283-294.

Mathieu, O., Probst, A. V., and Paszkowski, J. (2005). Distinct regulation of histone $\mathrm{H} 3$ methylation at lysines 27 and 9 by CpG methylation in Arabidopsis. Embo J 24, 2783-2791. 
Matzke, M., Matzke, A. J., and Kooter, J. M. (2001). RNA: guiding gene silencing. Science 293, 1080-1083.

Matzke, M. A., and Birchler, J. A. (2005). RNAi-mediated pathways in the nucleus. Nat Rev Genet 6, 24-35.

McCabe, D. C., and Caudill, M. A. (2005). DNA methylation, genomic silencing, and links to nutrition and cancer. Nutr Rev 63, 183-195.

McGrath, J., and Solter, D. (1984). Completion of mouse embryogenesis requires both the maternal and paternal genomes. Cell 37, 179-183.

Melzner, I., Scott, V., Dorsch, K., Fischer, P., Wabitsch, M., Bruderlein, S., Hasel, C., and Moller, P. (2002). Leptin gene expression in human preadipocytes is switched on by maturation-induced demethylation of distinct $\mathrm{CpG}$ in its proximal promoter. J Biol Chem 277, 45420-45427.

Mietz, J. A., and Kuff, E. L. (1990). Tissue and strain-specific patterns of endogenous proviral hypomethylation analyzed by two-dimensional gel electrophoresis. Proc Natl Acad Sci U S A 87, 2269-2273.

Moraes, R. C., Blondet, A., Birkenkamp-Demtroeder, K., Tirard, J., Orntoft, T. F., Gertler, A., Durand, P., Naville, D., and Begeot, M. (2003). Study of the alteration of gene expression in adipose tissue of diet-induced obese mice by microarray and reverse transcription-polymerase chain reaction analyses. Endocrinology 144, 4773-4782.

Morgan, H. D., Sutherland, H. G., Martin, D. I., and Whitelaw, E. (1999). Epigenetic inheritance at the agouti locus in the mouse. Nat Genet 23, 314-318.

Morison, I. M., Ramsay, J. P., and Spencer, H. G. (2005). A census of mammalian imprinting. Trends Genet 21, 457-465.

Musri, M. M., Corominola, H., Casamitjana, R., Gomis, R., and Parrizas, M. (2006). Histone H3 lysine 4 dimethylation signals the transcriptional competence of the adiponectin promoter in preadipocytes. J Biol Chem 281, 1718017188.

Mutskov, V., and Felsenfeld, G. (2004). Silencing of transgene transcription precedes methylation of promoter DNA and histone $\mathrm{H} 3$ lysine 9. Embo J 23, 138-149.

Nan, X., Campoy, F. J., and Bird, A. (1997). MeCP2 is a transcriptional repressor with abundant binding sites in genomic chromatin. Cell 88, 471-481.

Nicholson, J. M., Wood, C. M., Reynolds, C. D., Brown, A., Lambert, S. J., Chantalat, L., and Baldwin, J. P. (2004). Histone structures: targets for modifications by molecular assemblies. Ann N Y Acad Sci 1030, 644-655.

Niculescu, M. D., Craciunescu, C. N., and Zeisel, S. H. (2006). Dietary choline deficiency alters global and gene-specific DNA methylation in the developing hippocampus of mouse fetal brains. Faseb J 20, 43-49.

Nielsen, A. L., Ortiz, J. A., You, J., Oulad-Abdelghani, M., Khechumian, R., Gansmuller, A., Chambon, P., and Losson, R. (1999). Interaction with members of the heterochromatin protein 1 (HP1) family and histone deacetylation are differentially involved in transcriptional silencing by members of the TIF1 family. Embo J 18, 6385-6395.

O'Neill, L. P., Keohane, A. M., Lavender, J. S., McCabe, V., Heard, E., Avner, P., Brockdorff, N., and Turner, B. M. (1999). A developmental switch in $\mathrm{H} 4$ acetylation upstream of Xist plays a role in $\mathrm{X}$ chromosome inactivation. Embo J 18, 2897-2907.

Okano, M., Bell, D. W., Haber, D. A., and Li, E. (1999). DNA methyltransferases Dnmt3a and Dnmt3b are essential for de novo methylation and mammalian development. Cell 99, 247-257.

Padjen, K., Ratnam, S., and Storb, U. (2005). DNA methylation precedes chromatin modifications under the influence of the strain-specific modifier Ssm1. Mol Cell Biol 25, 4782-4791.

Pena, P. V., Davrazou, F., Shi, X., Walter, K. L., Verkhusha, V. V., Gozani, O., Zhao, R., and Kutateladze, T. G. (2006). Molecular mechanism of histone $\mathrm{H} 3 \mathrm{~K} 4 \mathrm{me} 3$ recognition by plant homeodomain of ING2. Nature 442, 100-103.

Peterson, C. L., and Laniel, M. A. (2004). Histones and histone modifications. Curr Biol 14, R546-551.

Plagge, A., Gordon, E., Dean, W., Boiani, R., Cinti, S., Peters, J., and Kelsey, G. (2004). The imprinted signaling protein $\mathrm{XL}$ alpha $\mathrm{s}$ is required for postnatal adaptation to feeding. Nat Genet 36, 818-826.

Rakyan, V. K., Blewitt, M. E., Druker, R., Preis, J. I., and Whitelaw, E. (2002). Metastable epialleles in mammals. Trends Genet 18, 348-351.

Rankinen, T., Zuberi, A., Chagnon, Y. C., Weisnagel, S. J., Argyropoulos, G., Walts, B., Perusse, L., and Bouchard, C. (2006). The human obesity gene map: the 2005 update. Obesity (Silver Spring) 14, 529-644.

Reik, W., Dean, W., and Walter, J. (2001). Epigenetic reprogramming in mammalian development. Science 293, 1089-1093.

Riggs, A. D. (1975). X inactivation, differentiation, and DNA methylation. Cytogenet Cell Genet 14, 9-25.

Robertson, K. D. (2005). DNA methylation and human disease. Nat Rev Genet 6, 597-610.

Rodenhiser, D., and Mann, M. (2006). Epigenetics and human disease: translating basic biology into clinical applications. Cmaj 174, 341-348.

Rosen, E. D., and Spiegelman, B. M. (2000). Molecular regulation of adipogenesis. Annu Rev Cell Dev Biol 16, 145-171.

Rountree, M. R., Bachman, K. E., and Baylin, S. B. (2000). DNMT1 binds HDAC2 and a new co-repressor, DMAP1, to form a complex at replication foci. Nat Genet 25, 269277.

Santos-Rosa, H., and Caldas, C. (2005). Chromatin modifier enzymes, the histone code and cancer. Eur $\mathrm{J}$ Cancer 41, 2381-2402.

Schubeler, D., Lorincz, M. C., Cimbora, D. M., Telling, A., Feng, Y. Q., Bouhassira, E. E., and Groudine, M. (2000). Genomic targeting of methylated DNA: influence of methylation on transcription, replication, chromatin structure, and histone acetylation. Mol Cell Biol 20, 9103-9112.

Shi, X., Hong, T., Walter, K. L., Ewalt, M., Michishita, E., Hung, T., Carney, D., Pena, P., Lan, F., Kaadige, M. R., et al. (2006). ING2 PHD domain links histone H3 lysine 4 methylation to active gene repression. Nature 442 , 96-99.

Sims, R. J., 3rd, Chen, C. F., Santos-Rosa, H., Kouzarides, T., Patel, S. S., and Reinberg, D. (2005). Human but not yeast CHD1 binds directly and selectively to histone $\mathrm{H} 3$ methylated at lysine 4 via its tandem chromodomains. J Biol Chem 280, 41789-41792.

Smith, F. M., Garfield, A. S., and Ward, A. (2006). Regulation of growth and metabolism by imprinted genes. Cytogenet Genome Res 113, 279-291.

Smith, S. R., and Ravussin, E. (2005). Genetic and physiological factors in obesity. J La State Med Soc 157 
Spec No 1, S12-18.

Sparago, A., Russo, S., Cerrato, F., Ferraiuolo, S., Castorina, P., Selicorni, A., Schwienbacher, C., Negrini, M., Ferrero, G. B., Silengo, M. C., et al. (2007). Mechanisms causing imprinting defects in familial Beckwith-Wiedemann syndrome with Wilms' tumour. Hum Mol Genet 16, 254264.

Speakman, J. R. (2004). Obesity: the integrated roles of environment and genetics. J Nutr 134, 2090S-2105S.

Surani, M. A. (1991). Genomic imprinting: developmental significance and molecular mechanism. Curr Opin Genet Dev 1, 241-246.

Surani, M. A., Barton, S. C., and Norris, M. L. (1984). Development of reconstituted mouse eggs suggests imprinting of the genome during gametogenesis. Nature 308, 548-550.

Takahashi, M., Kamei, Y., and Ezaki, O. (2005). Mest/Peg1 imprinted gene enlarges adipocytes and is a marker of adipocyte size. Am J Physiol Endocrinol Metab 288, E117-124.

Tamaru, H., and Selker, E. U. (2001). A histone H3 methyltransferase controls DNA methylation in Neurospora crassa. Nature 414, 277-283.

Valls, E., Sanchez-Molina, S., and Martinez-Balbas, M. A. (2005). Role of histone modifications in marking and activating genes through mitosis. J Biol Chem 280, 4259242600.

Varrault, A., Gueydan, C., Delalbre, A., Bellmann, A., Houssami, S., Aknin, C., Severac, D., Chotard, L., Kahli, M., Le Digarcher, A., et al. (2006). Zac1 regulates an imprinted gene network critically involved in the control of embryonic growth. Dev Cell 11, 711-722.

Vasicek, T. J., Zeng, L., Guan, X. J., Zhang, T., Costantini, F., and Tilghman, S. M. (1997). Two dominant mutations in the mouse fused gene are the result of transposon insertions. Genetics 147, 777-786.

Walsh, C. P., Chaillet, J. R., and Bestor, T. H. (1998). Transcription of IAP endogenous retroviruses is constrained by cytosine methylation. Nat Genet 20, 116-117.

Waterland, R. A., and Jirtle, R. L. (2003). Transposable elements: targets for early nutritional effects on epigenetic gene regulation. Mol Cell Biol 23, 5293-5300.

Weksberg, R., Smith, A. C., Squire, J., and Sadowski, P. (2003). Beckwith-Wiedemann syndrome demonstrates a role for epigenetic control of normal development. Hum Mol Genet 12 Spec No 1, R61-68.

Wolff, G. L., Kodell, R. L., Moore, S. R., and Cooney, C. A. (1998). Maternal epigenetics and methyl supplements affect agouti gene expression in Avy/a mice. Faseb $\mathrm{J} 12$, 949-957.

Yang, Y., Hu, J. F., Ulaner, G. A., Li, T., Yao, X., Vu, T. H., and Hoffman, A. R. (2003). Epigenetic regulation of Igf2/H19 imprinting at CTCF insulator binding sites. J Cell Biochem 90, 1038-1055.

Yokomori, N., Tawata, M., and Onaya, T. (1999). DNA demethylation during the differentiation of 3T3-L1 cells affects the expression of the mouse GLUT4 gene. Diabetes 48, 685-690.

Yokomori, N., Tawata, M., and Onaya, T. (2002). DNA demethylation modulates mouse leptin promoter activity during the differentiation of 3T3-L1 cells. Diabetologia 45, 140-148.

Zarich, S. W. (2006). Metabolic syndrome, diabetes and cardiovascular events: current controversies and recommendations. Minerva Cardioangiol 54, 195-214.

Zeschnigk, M., Schmitz, B., Dittrich, B., Buiting, K., Horsthemke, B., and Doerfler, W. (1997). Imprinted segments in the human genome: different DNA methylation patterns in the Prader-Willi/Angelman syndrome region as determined by the genomic sequencing method. Hum Mol Genet 6, 387-395.

Zhang, C. L., McKinsey, T. A., and Olson, E. N. (2002). Association of class II histone deacetylases with heterochromatin protein 1: potential role for histone methylation in control of muscle differentiation. Mol Cell Biol 22, 7302-7312.

Zhang, Y. (2003). Transcriptional regulation by histone ubiquitination and deubiquitination. Genes Dev 17, 27332740.

Zhang, Y. (2006). It takes a PHD to interpret histone methylation. Nat Struct Mol Biol 13, 572-574. 


\section{Further Reading}

Caister Academic Press is a leading academic publisher of advanced texts in microbiology, molecular biology and medical research. Full details of all our publications at caister.com

- MALDI-TOF Mass Spectrometry in Microbiology Edited by: M Kostrzewa, S Schubert (2016) www.caister.com/malditof

- Aspergillus and Penicillium in the Post-genomic Era Edited by: RP Vries, IB Gelber, MR Andersen (2016) www.caister.com/aspergillus2

- The Bacteriocins: Current Knowledge and Future Prospects Edited by: RL Dorit, SM Roy, MA Riley (2016)

www.caister.com/bacteriocins

- Omics in Plant Disease Resistance Edited by: V Bhadauria (2016) www.caister.com/opd

- Acidophiles: Life in Extremely Acidic Environments Edited by: R Quatrini, DB Johnson (2016) www.caister.com/acidophiles

- Climate Change and Microbial Ecology: Current Research and Future Trend

Edited by: J Marxsen (2016)

www.caister.com/climate

- Biofilms in Bioremediation: Current Research and Emerging Technologies

Edited by: G Lear (2016)

www.caister.com/biorem

- Microalgae: Current Research and Applications Edited by: MN Tsaloglou (2016) www.caister.com/microalgae

- Gas Plasma Sterilization in Microbiology: Theory, Applications, Pitfalls and New Perspectives Edited by: H Shintani, A Sakudo (2016) www.caister.com/gasplasma

- Virus Evolution: Current Research and Future Directions Edited by: SC Weaver, M Denison, M Roossinck, et al. (2016) www.caister.com/virusevol

- Arboviruses: Molecular Biology, Evolution and Control Edited by: N Vasilakis, DJ Gubler (2016) www.caister.com/arbo

- Shigella: Molecular and Cellular Biology Edited by: WD Picking, WL Picking (2016) www.caister.com/shigella

-Aquatic Biofilms: Ecology, Water Quality and Wastewater Treatment

Edited by: AM Romaní, H Guasch, MD Balaguer (2016)

www.caister.com/aquaticbiofilms

- Alphaviruses: Current Biology

Edited by: S Mahalingam, L Herrero, B Herring (2016)

www.caister.com/alpha

- Thermophilic Microorganisms

Edited by: F Li (2015)

www.caister.com/thermophile
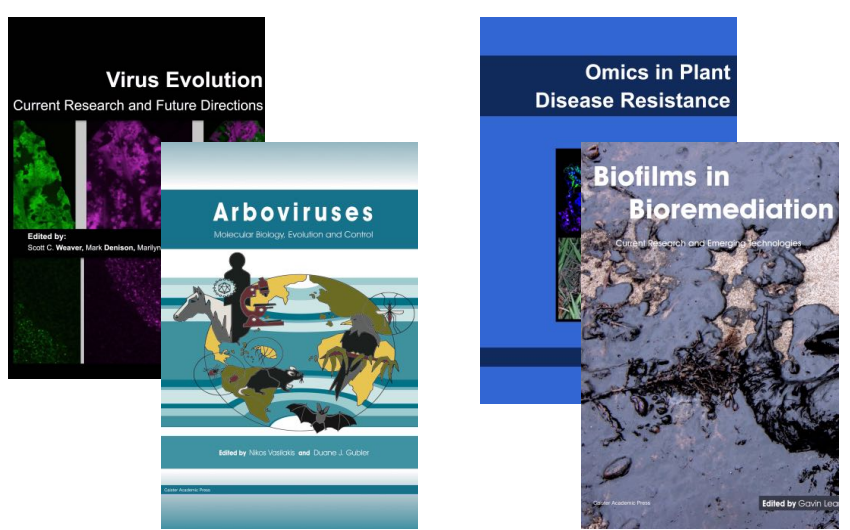
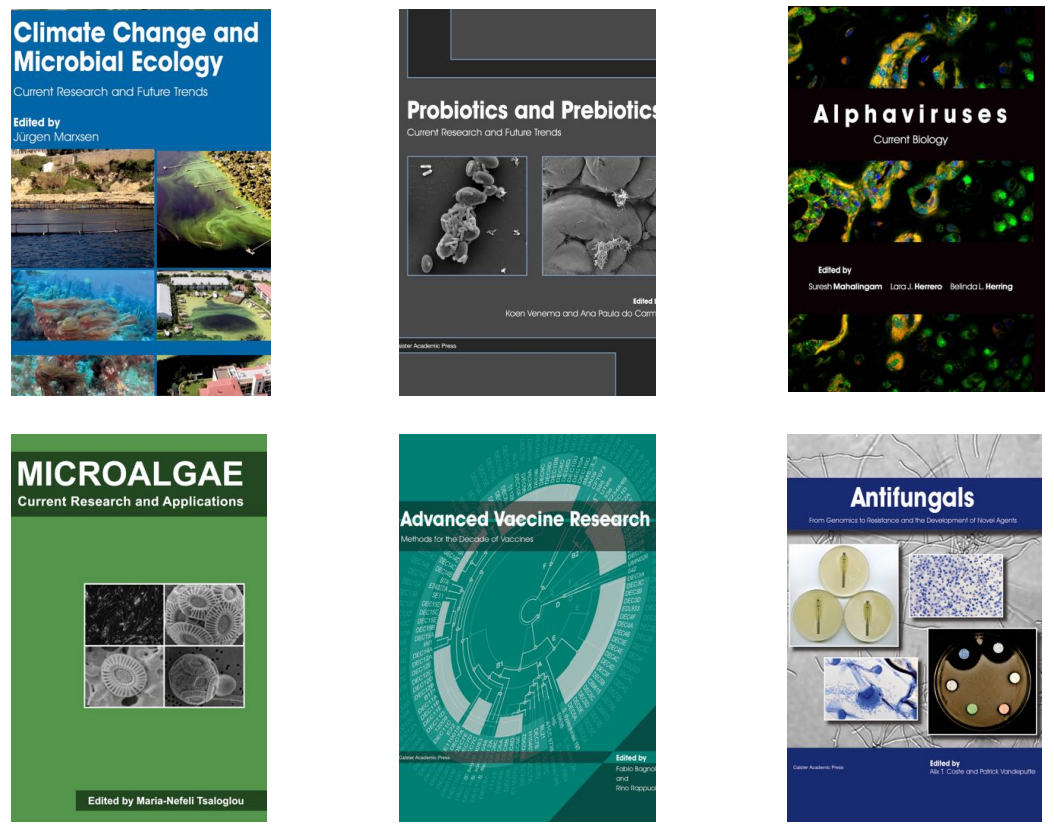

- Flow Cytometry in Microbiology: Technology and Applications Edited by: MG Wilkinson (2015) www.caister.com/flow

- Probiotics and Prebiotics: Current Research and Future Trends Edited by: K Venema, AP Carmo (2015) www.caister.com/probiotics

- Epigenetics: Current Research and Emerging Trends Edited by: BP Chadwick (2015) www.caister.com/epigenetics2015

- Corynebacterium glutamicum: From Systems Biology to Biotechnological Applications

Edited by: A Burkovski (2015)

www.caister.com/cory2

- Advanced Vaccine Research Methods for the Decade of Vaccines

Edited by: F Bagnoli, R Rappuoli (2015)

www.caister.com/vaccines

- Antifungals: From Genomics to Resistance and the Development of Novel Agents

Edited by: AT Coste, P Vandeputte (2015)

www.caister.com/antifungals

- Bacteria-Plant Interactions: Advanced Research and Future Trends Edited by: J Murillo, BA Vinatzer, RW Jackson, et al. (2015) www.caister.com/bacteria-plant

\section{- Aeromonas}

Edited by: J Graf (2015)

www.caister.com/aeromonas

- Antibiotics: Current Innovations and Future Trends

Edited by: S Sánchez, AL Demain (2015)

www.caister.com/antibiotics

- Leishmania: Current Biology and Contro Edited by: S Adak, R Datta (2015) www.caister.com/leish2

- Acanthamoeba: Biology and Pathogenesis (2nd edition) Author: NA Khan (2015)

www.caister.com/acanthamoeba2

- Microarrays: Current Technology, Innovations and Applications Edited by: Z He (2014)

www.caister.com/microarrays2

- Metagenomics of the Microbial Nitrogen Cycle: Theory, Methods and Applications

Edited by: D Marco (2014)

www.caister.com/n2 